\title{
Safety and Tolerability of Combinations of Empagliflozin and Linagliptin in Patients with Type 2 Diabetes: Pooled Data from Two Randomized Controlled Trials
}

Ralph A. DeFronzo • Christopher Lee - Sven Kohler

Received: March 1, 2018 / Published online: June 15, 2018

(C) The Author(s) 2018

\section{ABSTRACT}

Introduction: Two 52-week Phase III studies evaluated the efficacy and safety of once-daily combinations of empagliflozin/linagliptin as monotherapy or add-on to metformin in patients with type 2 diabetes (T2DM). The aim of this analysis was to further assess the safety and tolerability of empagliflozin/linagliptin compared with their individual components in patients with T2DM, using pooled data from these trials.

Methods: A total of 1363 patients were treated with empagliflozin $25 \mathrm{mg} /$ linagliptin $5 \mathrm{mg}$ $(n=273)$, empagliflozin $10 \mathrm{mg} /$ linagliptin $5 \mathrm{mg}$ $(n=272)$, empagliflozin $25 \mathrm{mg} \quad(n=276)$, empagliflozin $10 \mathrm{mg}(n=275)$, or linagliptin $5 \mathrm{mg} \quad(n=267)$. Adverse events (AEs) were assessed descriptively in patients who took $\geq 1$ dose of study drug.

Results: Total exposure was 251, 255, 256, 249, and 243 patient-years in the empagliflozin

Enhanced Digital Features To view enhanced digital features for this article go to https://doi.org/10.6084/ m9.figshare.6303932.

R. A. DeFronzo ( $₫)$

University of Texas Health Science Center,

San Antonio, TX, USA

e-mail: defronzo@uthscsa.edu

C. Lee $\cdot$ S. Kohler

Boehringer Ingelheim International $\mathrm{GmbH}$,

Ingelheim, Germany
$25 \mathrm{mg} /$ linagliptin $5 \mathrm{mg}$, empagliflozin $10 \mathrm{mg} /$ linagliptin $5 \mathrm{mg}$, empagliflozin $25 \mathrm{mg}$, empagliflozin $10 \mathrm{mg}$, and linagliptin $5 \mathrm{mg}$ groups, respectively. The proportion of patients with $\geq 1 \mathrm{AE}$ was similar across groups (70.4-74.9\%). The percentage of patients with confirmed hypoglycemic AEs (plasma glucose $\leq 70 \mathrm{mg} / \mathrm{dL}$ and/or requiring assistance) was low in all groups (1.1-2.2\%); none required assistance. Events consistent with urinary tract infection were reported in similar percentages of patients in all groups (11.4-13.8\%), and in a greater proportion of female than male patients. Events consistent with genital infection were reported in higher percentages of patients on empagliflozin/linagliptin or empagliflozin (4.0-6.5\%) than linagliptin $5 \mathrm{mg}(2.6 \%)$, and in a greater proportion of females than males. The risks of hypersensitivity reactions and events consistent with volume depletion were low across treatment groups.

Conclusion: Empagliflozin/linagliptin as monotherapy or add-on to metformin for 52 weeks was well tolerated in patients with T2DM, with safety profiles similar to individual components, including a low risk of hypoglycemia.

Funding: The Boehringer Ingelheim \& Eli Lilly and Company Diabetes Alliance.

Trial Registration: ClinicalTrials.gov identifiers, NCT01422876 \& NCT01422876. 
Keywords: Adverse drug event; Dipeptidyl peptidase-4 inhibitor; Drug side effects; Hypoglycemia; SGLT2 inhibitor

\section{INTRODUCTION}

Metformin is recommended as first-line pharmacotherapy for patients with type 2 diabetes (T2DM) in the American Diabetes Association guidelines [1]. While effective initially, metformin treatment alone often fails to maintain glycemic control as T2DM progresses [2-4], and additional glucose-lowering therapies, such as sodium glucose cotransporter 2 (SGLT2) inhibitors and dipeptidyl peptidase-4 (DPP-4) inhibitors, are required [1]. Using treatments in combination may be preferred to sequential addition for reasons including simplification of drug dosing regimen, reduced pill burden and increased treatment adherence [5-7].

Inhibition of SGLT2 in patients with T2DM reduces renal glucose reabsorption, thereby increasing urinary glucose excretion, leading to a reduction in plasma glucose levels in an insulin-independent manner [8-10]. Linagliptin reduces blood glucose in patients with T2DM by preventing degradation of incretin peptides such as glucagon-like peptide 1 (GLP-1), stimulating insulin release and inhibiting glucagon secretion [11]. The efficacy and safety of oncedaily combinations of empagliflozin/linagliptin as monotherapy or add-on to metformin in patients with T2DM were assessed in two double-blind 52-week Phase III studies. As add-on to metformin, combinations of empagliflozin 10 or $25 \mathrm{mg}$ with linagliptin $5 \mathrm{mg}$ significantly reduced HbA1c versus the individual components [12]. As initial therapy, empagliflozin $10 \mathrm{mg} /$ linagliptin $5 \mathrm{mg}$ significantly reduced HbA1c versus empagliflozin $10 \mathrm{mg}$ or linagliptin $5 \mathrm{mg}$, and empagliflozin $25 \mathrm{mg}$ /linagliptin $5 \mathrm{mg}$ significantly reduced HbA1c versus linagliptin $5 \mathrm{mg}$, but reductions in HbA1c were not significant versus empagliflozin $25 \mathrm{mg}$ [13]. In these trials, the safety profiles of empagliflozin/ linagliptin were similar to the known safety profiles of the individual components [12, 13]. We used the large pool of data from these two double-blind trials to conduct a detailed analysis of the safety and tolerability of oncedaily combinations of empagliflozin/linagliptin compared with their individual components for 52 weeks in patients with T2DM.

\section{METHODS}

\section{Patients}

Data were pooled from two Phase III, randomized, double-blind, parallel-group studies in patients with T2DM, one that evaluated combinations of empagliflozin/linagliptin as initial therapy (trial registration: ClinicalTrials.gov identifier, NCT01422876) [13], and one that evaluated combinations of empagliflozin/linagliptin as second-line therapy in patients inadequately controlled on metformin (trial registration: ClinicalTrials.gov identifier, NCT01422876) [12]. In both studies, eligible patients were aged $\geq 18$ years with body mass index (BMI) $\leq 45 \mathrm{~kg} / \mathrm{m}^{2}$ and $\mathrm{HbA} 1 \mathrm{c} \geq 7 \%$ to $\leq 10.5 \%$ at screening. In the initial therapy study, patients who had not received treatment with an oral antidiabetes therapy, GLP-1 analogue, or insulin for $\geq 12$ weeks were randomized 1:1:1:1:1 to empagliflozin $25 \mathrm{mg} /$ linagliptin $5 \mathrm{mg}$ as a fixed dose combination (FDC) tablet, empagliflozin $10 \mathrm{mg} /$ linagliptin $5 \mathrm{mg}$ as a FDC tablet, empagliflozin $25 \mathrm{mg}$, empagliflozin $10 \mathrm{mg}$, or linagliptin $5 \mathrm{mg}$ for 52 weeks [13]. In the add-on to metformin study, patients who were receiving metformin immediate release $(\geq 1500 \mathrm{mg} /$ day, maximum tolerated dose, or maximum dose according to local label) at a dose unchanged for $\geq 12$ weeks were randomized 1:1:1:1:1 to empagliflozin $25 \mathrm{mg} /$ linagliptin $5 \mathrm{mg}$ as an FDC tablet, empagliflozin $10 \mathrm{mg} /$ linagliptin $5 \mathrm{mg} \quad$ FDC tablet, empagliflozin $25 \mathrm{mg}$, empagliflozin $10 \mathrm{mg}$, or linagliptin $5 \mathrm{mg}$ for 52 weeks as addon to metformin at an unchanged dose [12]. FDC tablets, empagliflozin tablets and linagliptin tablets were taken once daily in the morning. The studies were conducted in 197 centers in 22 countries. All procedures followed were in accordance with the ethical standards of the responsible committee on human experimentation (institutional and national) and with the 
Declaration of Helsinki in accordance with the International Conference on Harmonization Harmonized Tripartite Guideline for Good Clinical Practice. An independent ethics committee or institutional review board approved the clinical protocol at each participating center. All participants gave signed and dated informed consent prior to inclusion.

\section{Assessments and Data Analyses}

Safety and tolerability over 52 weeks was assessed via reporting of adverse events (AEs) and laboratory parameters. AEs assessed were those reported by investigators, coded according to preferred terms in the Medical Dictionary for Regulatory Activities (MedDRA) version 16.0. The assessment of AEs was based on events that occurred during treatment or within 7 days after the last dose of the study drug. AEs classified as serious were as reported by the investigator. A mild AE was defined as an awareness of signs or symptoms which are easily tolerated, as judged by the investigator. A moderate $\mathrm{AE}$ was defined as an $\mathrm{AE}$ judged by the investigator to create enough discomfort to cause interference with usual activity. A severe AE was defined as an $\mathrm{AE}$ judged by the investigator to be incapacitating or causing inability to work or to perform usual activities. A serious AE was one that resulted in death, was immediately life-threatening, resulted in persistent or significant disability/incapacity, required or prolonged patient hospitalization, was a congenital anomaly/birth defect, or was deemed serious for any other reason based on appropriate medical judgment. AEs of interest included confirmed hypoglycemic AEs (plasma glucose $\leq 70 \mathrm{mg} / \mathrm{dL}$ and/ or requiring assistance), events consistent with urinary tract infection (UTI), genital infection, and volume depletion, hypersensitivity reactions, pancreatitis and cancer. Assessment of laboratory parameters included changes from baseline in hematocrit, electrolytes, lipids, estimated glomerular filtration rate (eGFR; according to the Modification of Diet in Renal Disease equation) and uric acid. Analyses were descriptive and based on patients who received $\geq 1$ dose of study drug.

\section{RESULTS}

\section{Patient Disposition, Exposure and Baseline Characteristics}

A total of 1363 patients received $\geq 1$ dose of study drug, 677 as initial therapy and 686 as add-on to metformin. Total exposures were 251, $255,256,249$, and 243 patient-years in the empagliflozin $25 \mathrm{mg}$ /linagliptin $5 \mathrm{mg}$, empagliflozin $10 \mathrm{mg} /$ linagliptin $5 \mathrm{mg}$, empagliflozin $25 \mathrm{mg}$, empagliflozin $10 \mathrm{mg}$, and linagliptin $5 \mathrm{mg}$ groups, respectively. Baseline demographics and clinical characteristics were similar among the five treatment groups (Table 1).

\section{Summary of Adverse Events}

The proportion of patients with $\geq 1 \mathrm{AE}$ was similar across treatment groups (Table 2). Most events were mild or moderate in intensity; severe events were reported in $7.0 \%$ of patients on empagliflozin $25 \mathrm{mg} /$ linagliptin $5 \mathrm{mg}, 6.3 \%$ on empagliflozin $10 \mathrm{mg} /$ linagliptin $5 \mathrm{mg}, 5.1 \%$ on empagliflozin $25 \mathrm{mg}, 6.2 \%$ on empagliflozin $10 \mathrm{mg}$ and $3.4 \%$ on linagliptin $5 \mathrm{mg}$. Serious AEs were reported in $4.4 \%$ of patients on empagliflozin $25 \mathrm{mg} /$ linagliptin $5 \mathrm{mg}, 5.9 \%$ on empagliflozin $10 \mathrm{mg} /$ linagliptin $5 \mathrm{mg}, 6.9 \%$ on empagliflozin $25 \mathrm{mg}, 5.8 \%$ on empagliflozin $10 \mathrm{mg}$ and $3.7 \%$ on linagliptin. Similar proportions of patients discontinued because of AEs across the treatment groups. There were two deaths in the empagliflozin $10 \mathrm{mg} /$ linagliptin $5 \mathrm{mg}$ group (hypertensive heart disease and hemorrhagic stroke), two deaths in the empagliflozin $25 \mathrm{mg}$ group (meningitis tuberculosis and hepatic mass), and two deaths in the empagliflozin $10 \mathrm{mg}$ group (lung neoplasm/ metastatic non-small cell lung cancer and brain edema). The most common AE preferred terms reported were urinary tract infection, headache, upper respiratory tract infection, nasopharyngitis, hyperglycemia and arthralgia (Table 2). No patients experienced worsening of heart failure or were hospitalized due to heart failure. There were no cases of lower limb amputation in any treatment group. 
Table 1 Baseline characteristics

\begin{tabular}{|c|c|c|c|c|c|}
\hline & $\begin{array}{l}\text { Empagliflozin } \\
25 \mathrm{mg} / \text { linagliptin } \\
5 \mathrm{mg}(n=273)\end{array}$ & $\begin{array}{l}\text { Empagliflozin } \\
10 \mathrm{mg} / \text { linagliptin } \\
5 \mathrm{mg}(n=272)\end{array}$ & $\begin{array}{l}\text { Empagliflozin } \\
25 \mathrm{mg} \\
(n=276)\end{array}$ & $\begin{array}{l}\text { Empagliflozin } \\
10 \mathrm{mg} \\
(n=275)\end{array}$ & $\begin{array}{l}\text { Linagliptin } \\
5 \mathrm{mg} \\
(n=267)\end{array}$ \\
\hline Male & $145(53.1)$ & $158(58.1)$ & $144(52.2)$ & $146(53.1)$ & $142(53.2)$ \\
\hline Age, years & $55.7(10.2)$ & $55.7(10.0)$ & $55.6(9.8)$ & $54.9(10.5)$ & $55.0(10.8)$ \\
\hline \multicolumn{6}{|l|}{ Race } \\
\hline White & $205(75.1)$ & $204(75.0)$ & $194(70.3)$ & $209(76.0)$ & $201(75.3)$ \\
\hline Asian & $34(12.5)$ & $32(11.8)$ & $40(14.5)$ & $32(11.6)$ & $32(12.0)$ \\
\hline Black/African American & $17(6.2)$ & $24(8.8)$ & $24(8.7)$ & $17(6.2)$ & $17(6.4)$ \\
\hline Other & $17(6.2)$ & $12(4.4)$ & $18(6.5)$ & $17(6.2)$ & $17(6.4)$ \\
\hline \multicolumn{6}{|c|}{ Time since diagnosis of type 2 diabetes, years } \\
\hline$\leq 1$ & $53(19.4)$ & $65(23.9)$ & $58(21.0)$ & $57(20.7)$ & $60(22.5)$ \\
\hline$>1-5$ & $101(37.0)$ & $97(35.7)$ & $100(36.2)$ & $114(41.5)$ & $106(39.7)$ \\
\hline$>5-10$ & $75(27.5)$ & $73(26.8)$ & $75(27.2)$ & $55(20.0)$ & $65(24.3)$ \\
\hline$>10$ & $44(16.1)$ & $37(13.6)$ & $43(15.6)$ & $49(17.8)$ & $36(13.5)$ \\
\hline HbAlc, \% & $7.94(0.87)$ & $8.01(0.89)$ & $8.01(0.90)$ & $8.01(0.98)$ & $8.03(0.89)$ \\
\hline Weight, kg & $86.8(19.4)$ & $86.9(18.7)$ & $87.2(18.6)$ & $86.8(21.2)$ & $87.4(19.7)$ \\
\hline Body mass index, $\mathrm{kg} / \mathrm{m}^{2}$ & $31.3(5.5)$ & $31.1(5.6)$ & $31.5(5.5)$ & $31.2(5.5)$ & $31.2(5.8)$ \\
\hline $\begin{array}{l}\text { Systolic blood pressure, } \\
\text { mmHg }\end{array}$ & $129.7(15.2)$ & $128.9(14.7)$ & $129.1(14.0)$ & $130.1(15.1)$ & $128.0(13.9)$ \\
\hline $\begin{array}{l}\text { Diastolic blood pressure, } \\
\mathrm{mmHg}\end{array}$ & $78.4(9.1)$ & $78.7(8.4)$ & $79.3(8.9)$ & $79.7(9.1)$ & $78.0(8.8)$ \\
\hline $\begin{array}{l}\text { Estimated glomerular } \\
\text { filtration rate } \\
(\mathrm{MDRD}), \mathrm{mL} / \mathrm{min} / \\
1.73 \mathrm{~m}^{2}\end{array}$ & $88.9(18.8)$ & $88.5(17.9)$ & $89.5(18.4)$ & $89.8(19.4)$ & $89.7(20.1)$ \\
\hline
\end{tabular}

Data are number of patients (\%) or mean (SD) in patients treated with $\geq 1$ dose of study drug $M D R D$ Modification of Diet in Renal Disease equation

\section{Hypoglycemia}

The proportion of patients with confirmed hypoglycemic AEs was low and similar in all treatment groups $(1.8 \%, 1.1 \%, 2.2 \%, 2.2 \%$ and $1.5 \%$ of patients on empagliflozin $25 \mathrm{mg} / \mathrm{li}-$ nagliptin $5 \mathrm{mg}$, empagliflozin $10 \mathrm{mg} /$ linagliptin $5 \mathrm{mg}$, empagliflozin $25 \mathrm{mg}$, empagliflozin $10 \mathrm{mg}$ and linagliptin $5 \mathrm{mg}$, respectively; Table 3). No patients experienced confirmed hypoglycemic AEs that required assistance and no patients discontinued due to hypoglycemia.

\section{Urinary Tract Infection}

Events consistent with UTI were reported in a similar proportion of patients in each treatment group (11.4-13.8\%) (Table 3). Notably, there was no increase in events consistent with UTI in any of the four empagliflozin treatment groups 
Table 2 Summary of number of patients with AEs

\begin{tabular}{|c|c|c|c|c|c|}
\hline & $\begin{array}{l}\text { Empagliflozin } \\
25 \mathrm{mg} / \text { linagliptin } \\
5 \mathrm{mg}(n=273)\end{array}$ & $\begin{array}{l}\text { Empagliflozin } \\
10 \mathrm{mg} / \text { linagliptin } \\
5 \mathrm{mg}(n=272)\end{array}$ & $\begin{array}{l}\text { Empagliflozin } \\
25 \mathrm{mg} \\
(n=276)\end{array}$ & $\begin{array}{l}\text { Empagliflozin } \\
10 \text { mg } \\
(n=275)\end{array}$ & $\begin{array}{l}\text { Linagliptin } \\
5 \mathrm{mg} \\
(n=267)\end{array}$ \\
\hline One or more $\mathrm{AE}(\mathrm{s})$ & $201(73.6)$ & $193(71.0)$ & $196(71.0)$ & $206(74.9)$ & $188(70.4)$ \\
\hline \multicolumn{6}{|l|}{ Most common $\mathrm{AEs}^{\mathrm{a}}$} \\
\hline Urinary tract infection & $27(9.9)$ & $29(10.7)$ & $25(9.1)$ & $30(10.9)$ & $27(10.1)$ \\
\hline Headache & $16(5.9)$ & $15(5.5)$ & $13(4.7)$ & $19(6.9)$ & $24(9.0)$ \\
\hline $\begin{array}{l}\text { Upper respiratory tract } \\
\text { infection }\end{array}$ & $19(7.0)$ & $19(7.0)$ & $18(6.5)$ & $13(4.7)$ & $16(6.0)$ \\
\hline Nasopharyngitis & $18(6.6)$ & $16(5.9)$ & $10(3.6)$ & $16(5.8)$ & $20(7.5)$ \\
\hline Hyperglycemia & $8(2.9)$ & $8(2.9)$ & $12(4.3)$ & $13(4.7)$ & $24(9.0)$ \\
\hline Arthralgia & $5(1.8)$ & $14(5.1)$ & $13(4.7)$ & $10(3.6)$ & $12(4.5)$ \\
\hline $\begin{array}{l}\text { One or more drug- } \\
\text { related }^{\mathrm{b}} \mathrm{AE}(\mathrm{s})\end{array}$ & $41(15.0)$ & $37(13.6)$ & $48(17.4)$ & $42(15.3)$ & $32(12.0)$ \\
\hline $\begin{array}{l}\text { One or more } \\
\mathrm{AE}(\mathrm{s}) \text { leading to } \\
\text { treatment } \\
\text { discontinuation }\end{array}$ & $12(4.4)$ & $10(3.7)$ & $9(3.3)$ & $16(5.8)$ & $6(2.2)$ \\
\hline $\begin{array}{l}\text { One or more severe } \\
\mathrm{AE}(\mathrm{s})\end{array}$ & $19(7.0)$ & $17(6.3)$ & $14(5.1)$ & $17(6.2)$ & $9(3.4)$ \\
\hline $\begin{array}{l}\text { One or more serious } \\
\qquad \mathrm{AE}(\mathrm{s})\end{array}$ & $12(4.4)$ & $16(5.9)$ & $19(6.9)$ & $16(5.8)$ & $10(3.7)$ \\
\hline Deaths & 0 & $2(0.7)$ & $2(0.7)$ & $2(0.7)$ & 0 \\
\hline
\end{tabular}

Data are number of patients (\%) with $\geq 1$ event in patients treated with $\geq 1$ dose of study drug

a Preferred terms reported in $\geq 5 \%$ of patients in any treatment group

b As defined by the investigator

compared with the linagliptin group. Of patients who experienced an event consistent with UTI, most experienced only one event (71.0\%, 79.4\%, $66.7 \%, 89.5 \%$, and $82.4 \%$ of patients on empagliflozin $25 \mathrm{mg} /$ linagliptin $5 \mathrm{mg}$, empagliflozin $10 \mathrm{mg} /$ linagliptin $5 \mathrm{mg}$, empagliflozin $25 \mathrm{mg}$, empagliflozin $10 \mathrm{mg}$ and linagliptin $5 \mathrm{mg}$, respectively). A greater proportion of female than male patients in each group experienced an event consistent with UTI. Of patients who experienced events consistent with UTI, their worst reported episodes were mild in $80.6 \%, 76.5 \%, 60.6 \%, 78.9 \%$ and $85.3 \%$ of patients on empagliflozin $25 \mathrm{mg} /$ linagliptin $5 \mathrm{mg}$, empagliflozin $10 \mathrm{mg} / \mathrm{li}-$ nagliptin $5 \mathrm{mg}$, empagliflozin $25 \mathrm{mg}$, empagliflozin $10 \mathrm{mg}$ and linagliptin $5 \mathrm{mg}$, respectively, and reported events were moderate in $19.4 \%$, $23.5 \%, 36.4 \%, 18.4 \%$ and $11.8 \%$ of patients on empagliflozin $25 \mathrm{mg}$ /linagliptin $5 \mathrm{mg}$, empagliflozin $10 \mathrm{mg} /$ linagliptin $5 \mathrm{mg}$, empagliflozin $25 \mathrm{mg}$, empagliflozin $10 \mathrm{mg}$ and linagliptin $5 \mathrm{mg}$, respectively. Events consistent with UTI led to discontinuation in two patients on empagliflozin $10 \mathrm{mg}$. Events consistent with UTI that required or prolonged hospitalization were reported in $1.1 \%, 0.4 \%$ and $0.4 \%$ of patients in empagliflozin $25 \mathrm{mg}$, empagliflozin 
Table 3 Number of patients with AEs of interest

\begin{tabular}{|c|c|c|c|c|c|}
\hline & $\begin{array}{l}\text { Empagliflozin } 25 \mathrm{mg} / \\
\text { linagliptin } 5 \mathrm{mg} \\
(n=273)\end{array}$ & $\begin{array}{l}\text { Empagliflozin } \\
10 \mathrm{mg} / \text { linagliptin } \\
5 \mathrm{mg}(n=272)\end{array}$ & $\begin{array}{l}\text { Empagliflozin } \\
25 \mathrm{mg} \\
(n=276)\end{array}$ & $\begin{array}{l}\text { Empagliflozin } \\
10 \mathrm{mg} \\
(n=275)\end{array}$ & $\begin{array}{l}\text { Linagliptin } \\
5 \mathrm{mg} \\
(n=267)\end{array}$ \\
\hline $\begin{array}{l}\text { Confirmed } \\
\text { hypoglycemic AEs }\end{array}$ & $5(1.8)$ & $3(1.1)$ & $6(2.2)$ & $6(2.2)$ & $4(1.5)$ \\
\hline $\begin{array}{l}\text { Events requiring } \\
\text { assistance }\end{array}$ & 0 & 0 & 0 & 0 & 0 \\
\hline $\begin{array}{l}\text { Events consistent } \\
\text { with urinary tract } \\
\text { infection }^{\mathrm{b}}\end{array}$ & $31(11.4)$ & $34(12.5)$ & $33(12.0)$ & $38(13.8)$ & $34(12.7)$ \\
\hline Female & $25(19.5)$ & $27(23.7)$ & $28(21.2)$ & $29(22.5)$ & $29(23.2)$ \\
\hline Male & $6(4.1)$ & $7(4.4)$ & $5(3.5)$ & $9(6.2)$ & $5(3.5)$ \\
\hline $\begin{array}{l}\text { Events consistent } \\
\text { with genital } \\
\text { infection }^{c}\end{array}$ & $11(4.0)$ & $12(4.4)$ & $18(6.5)$ & $18(6.5)$ & $7(2.6)$ \\
\hline Female & $4(3.1)$ & $9(7.9)$ & $14(10.6)$ & $11(8.5)$ & $4(3.2)$ \\
\hline Male & $7(4.8)$ & $3(1.9)$ & $4(2.8)$ & $7(4.8)$ & $3(2.1)$ \\
\hline $\begin{array}{l}\text { Events consistent } \\
\text { with volume } \\
\text { depletion }^{\mathrm{d}}\end{array}$ & $2(0.7)$ & $5(1.8)$ & $2(0.7)$ & $1(0.4)$ & $4(1.5)$ \\
\hline Dehydration & $1(0.4)$ & $1(0.4)$ & $1(0.4)$ & 0 & $2(0.7)$ \\
\hline Hypotension & $1(0.4)$ & $2(0.7)$ & 0 & $1(0.4)$ & $2(0.7)$ \\
\hline Syncope & 0 & $2(0.7)$ & $2(0.7)$ & 0 & 0 \\
\hline $\begin{array}{l}\text { Orthostatic } \\
\text { hypotension }\end{array}$ & 0 & 0 & 0 & 0 & $1(0.4)$ \\
\hline $\begin{array}{l}\text { Hypersensitivity } \\
\text { reactions }^{\mathrm{e}}\end{array}$ & $3(1.1)$ & $2(0.7)$ & $2(0.7)$ & $2(0.7)$ & $1(0.4)$ \\
\hline Asthma & 0 & $1(0.4)$ & 0 & $2(0.7)$ & 0 \\
\hline Urticaria & 0 & $1(0.4)$ & $2(0.7)$ & 0 & 0 \\
\hline Angiodema & $1(0.4)$ & 0 & 0 & 0 & $1(0.4)$ \\
\hline Asthmatic crisis & $1(0.4)$ & 0 & 0 & 0 & 0 \\
\hline Eyelid edema & $1(0.4)$ & 0 & 0 & 0 & 0 \\
\hline Pancreatitis ${ }^{\mathrm{f}}$ & $1(0.4)$ & 0 & 0 & 0 & $1(0.4)$ \\
\hline Acute pancreatitis & $1(0.4)$ & 0 & 0 & 0 & 0 \\
\hline $\begin{array}{l}\text { Chronic } \\
\text { pancreatitis }\end{array}$ & 0 & 0 & 0 & 0 & $1(0.4)$ \\
\hline
\end{tabular}


Table 3 continued

\begin{tabular}{|c|c|c|c|c|c|}
\hline & $\begin{array}{l}\text { Empagliflozin } 25 \mathrm{mg} / \\
\text { linagliptin } 5 \mathrm{mg} \\
(n=273)\end{array}$ & $\begin{array}{l}\text { Empagliflozin } \\
10 \mathrm{mg} / \text { linagliptin } \\
5 \mathrm{mg}(n=272)\end{array}$ & $\begin{array}{l}\text { Empagliflozin } \\
25 \mathrm{mg} \\
(n=276)\end{array}$ & $\begin{array}{l}\text { Empagliflozin } \\
10 \mathrm{mg} \\
(n=275)\end{array}$ & $\begin{array}{l}\text { Linagliptin } \\
5 \mathrm{mg} \\
(n=267)\end{array}$ \\
\hline $\begin{array}{l}\text { Decreased renal } \\
\text { function }^{\mathrm{g}}\end{array}$ & $1(0.4)$ & 0 & 0 & 0 & $1(0.4)$ \\
\hline Acute renal failure & 0 & 0 & 0 & 0 & $1(0.4)$ \\
\hline Renal impairment & $1(0.4)$ & 0 & 0 & 0 & 0 \\
\hline Cancer events & $5(1.8)$ & $2(0.7)$ & $2(0.7)$ & $2(0.7)$ & $2(0.7)$ \\
\hline $\begin{array}{l}\text { Adenoid cystic } \\
\text { carcinoma }\end{array}$ & 0 & 0 & 0 & $1(0.4)$ & 0 \\
\hline Basal cell carcinoma & $1(0.4)$ & 0 & $1(0.4)$ & 0 & 0 \\
\hline Breast cancer & $1(0.4)$ & 0 & 0 & 0 & 0 \\
\hline Renal cancer $^{\text {h }}$ & $2(0.7)$ & 0 & 0 & 0 & 0 \\
\hline $\begin{array}{l}\text { Gastrointestinal } \\
\text { carcinoma }\end{array}$ & 0 & $1(0.4)$ & 0 & 0 & 0 \\
\hline Lung cancer ${ }^{\mathrm{i}}$ & 0 & $1(0.4)$ & 0 & $1(0.4)$ & 0 \\
\hline $\begin{array}{l}\text { Metastases to } \\
\text { peritoneum }\end{array}$ & 0 & 0 & $1(0.4)$ & 0 & 0 \\
\hline Ovarian cancer & 0 & 0 & $1(0.4)$ & 0 & 0 \\
\hline Prostate cancer $^{\mathrm{j}}$ & $1(0.4)$ & 0 & 0 & 0 & $1(0.4)$ \\
\hline $\begin{array}{l}\text { Squamous cell } \\
\text { carcinoma }\end{array}$ & 0 & 0 & 0 & 0 & $1(0.4)$ \\
\hline
\end{tabular}

Data are number of patients (\%) with $\geq 1$ event in patients treated with $\geq 1$ dose of study drug $S M Q$ standardized, MedDRA query Medical Dictionary for Regulatory Activities

a Plasma glucose $\leq 70 \mathrm{mg} / \mathrm{dL}$ and/or requiring assistance

b Based on 70 preferred terms

c Based on 89 preferred terms

d Based on 8 preferred terms

e Based on 3 SMQs

f Based on 1 SMQ and 1 preferred term

g Based on 1 SMQ

h Based on preferred terms: clear cell renal cell carcinoma/renal cancer

i Based on preferred terms: lung adenocarcinoma/lung neoplasm/non-small cell lung cancer metastatic

j Based on preferred terms: prostate cancer/prostatic specific antigen increased

$10 \mathrm{mg}$, and linagliptin $5 \mathrm{mg}$ groups, respectively, and none in the combination therapy groups. Acute pyelonephritis was reported in one patient who was on linagliptin $5 \mathrm{mg}$ : the event was severe in intensity and was considered to be related to the study drug. Chronic pyelonephritis was reported in two patients: one patient on empagliflozin $10 \mathrm{mg}$ experienced chronic pyelonephritis that was mild in intensity and was not considered to be related to study drug; one patient on empagliflozin $25 \mathrm{mg}$ experienced moderate exacerbation of 
chronic pyelonephritis that did not lead to discontinuation of the study drug.

\section{Genital Infection}

Events consistent with genital infection were reported in $4.0 \%$ of patients on empagliflozin $25 \mathrm{mg} /$ linagliptin $5 \mathrm{mg}, 4.4 \%$ on empagliflozin $10 \mathrm{mg} /$ linagliptin $5 \mathrm{mg}, 6.5 \%$ on empagliflozin $25 \mathrm{mg}, 6.5 \%$ on empagliflozin $10 \mathrm{mg}$ and $2.6 \%$ on linagliptin $5 \mathrm{mg}$ (Table 3). Of patients who experienced an event consistent with genital infection, most experienced only one event $(81.8 \%, 83.3 \%, 66.7 \%, 77.8 \%$ and $85.7 \%$ of patients on empagliflozin $25 \mathrm{mg} /$ linagliptin $5 \mathrm{mg}$, empagliflozin $10 \mathrm{mg} /$ linagliptin $5 \mathrm{mg}$, empagliflozin $25 \mathrm{mg}$, empagliflozin $10 \mathrm{mg}$ and linagliptin $5 \mathrm{mg}$, respectively). Events consistent with genital infection were reported in a greater proportion of female than male patients in all groups except empagliflozin $25 \mathrm{mg} / \mathrm{li}-$ nagliptin $5 \mathrm{mg}$ (Table 3). Of patients who experienced events consistent with genital infection, reported events were mild in $54.5 \%$, $83.3 \%, 61.1 \%, 72.2 \%$ and $57.1 \%$ of patients on empagliflozin $25 \mathrm{mg} /$ linagliptin $5 \mathrm{mg}$, empagliflozin $10 \mathrm{mg} /$ linagliptin $5 \mathrm{mg}$, empagliflozin $25 \mathrm{mg}$, empagliflozin $10 \mathrm{mg}$ and linagliptin $5 \mathrm{mg}$, respectively, and reported events were moderate in $45.5 \%, 16.7 \%, 38.9 \%, 22.2 \%$ and $42.9 \%$ of patients on empagliflozin $25 \mathrm{mg} / \mathrm{li}$ nagliptin $5 \mathrm{mg}$, empagliflozin $10 \mathrm{mg} /$ linagliptin $5 \mathrm{mg}$, empagliflozin $25 \mathrm{mg}$, empagliflozin $10 \mathrm{mg}$ and linagliptin $5 \mathrm{mg}$, respectively. Events consistent with genital infection led to discontinuation in one patient on empagliflozin $25 \mathrm{mg} /$ linagliptin $5 \mathrm{mg}$, two patients on empagliflozin $25 \mathrm{mg}$ and one on empagliflozin $10 \mathrm{mg}$. No patients experienced genital infections that required or prolonged hospitalization.

\section{Volume Depletion}

Events consistent with volume depletion were reported in two patients on empagliflozin $25 \mathrm{mg} /$ linagliptin $5 \mathrm{mg}$ (dehydration and hypotension), five on empagliflozin $10 \mathrm{mg} / \mathrm{li}$ nagliptin $5 \mathrm{mg}$ (dehydration, hypotension, and syncope), two on empagliflozin $25 \mathrm{mg}$ (dehydration and syncope), one on empagliflozin $10 \mathrm{mg}$ (hypotension) and four on linagliptin $5 \mathrm{mg}$ (dehydration, hypotension, and orthostatic hypotension) (Table 3). Serious events consistent with volume depletion were reported in one patient on empagliflozin $10 \mathrm{mg} / \mathrm{li}$ nagliptin $5 \mathrm{mg}$ (hypotension), two on empagliflozin $25 \mathrm{mg}$ (dehydration and syncope) and two on linagliptin $5 \mathrm{mg}$ (dehydration and hypotension).

\section{Hypersensitivity Reactions, Pancreatitis and Diabetic Ketoacidosis}

Hypersensitivity reactions were reported in three patients on empagliflozin $25 \mathrm{mg} / \mathrm{li}$ nagliptin $5 \mathrm{mg}$ (angioedema, asthmatic crisis, and eyelid edema), two on empagliflozin $10 \mathrm{mg} /$ linagliptin $5 \mathrm{mg}$ (asthma and urticaria), two on empagliflozin $25 \mathrm{mg}$ (urticaria), two on empagliflozin $10 \mathrm{mg}$ (asthma) and one on linagliptin $5 \mathrm{mg}$ (angiodema) (Table 3). Acute pancreatitis was reported in one patient on empagliflozin $25 \mathrm{mg} /$ linagliptin $5 \mathrm{mg}$ (Table 3). Chronic pancreatitis was reported in one patient on linagliptin $5 \mathrm{mg}$ after approximately 11 months of treatment; the investigator did not consider the pancreatitis to be related to the study medication and did not discontinue or reduce the study medication. No diabetic ketoacidosis AEs were reported.

\section{Renal Adverse Events and Laboratory Parameters}

Changes from baseline in eGFR were generally small and similar in all treatment groups (Fig. 1). Decreased renal function AEs were reported in one patient on empagliflozin $25 \mathrm{mg} /$ linagliptin $5 \mathrm{mg}$ (renal impairment) and one patient on linagliptin $5 \mathrm{mg}$ (acute renal failure) (Table 3).

\section{Cancer}

Cancer events were reported in five patients on empagliflozin $25 \mathrm{mg} /$ linagliptin $5 \mathrm{mg}$ and two patients in each of the other groups (Table 3 ). 


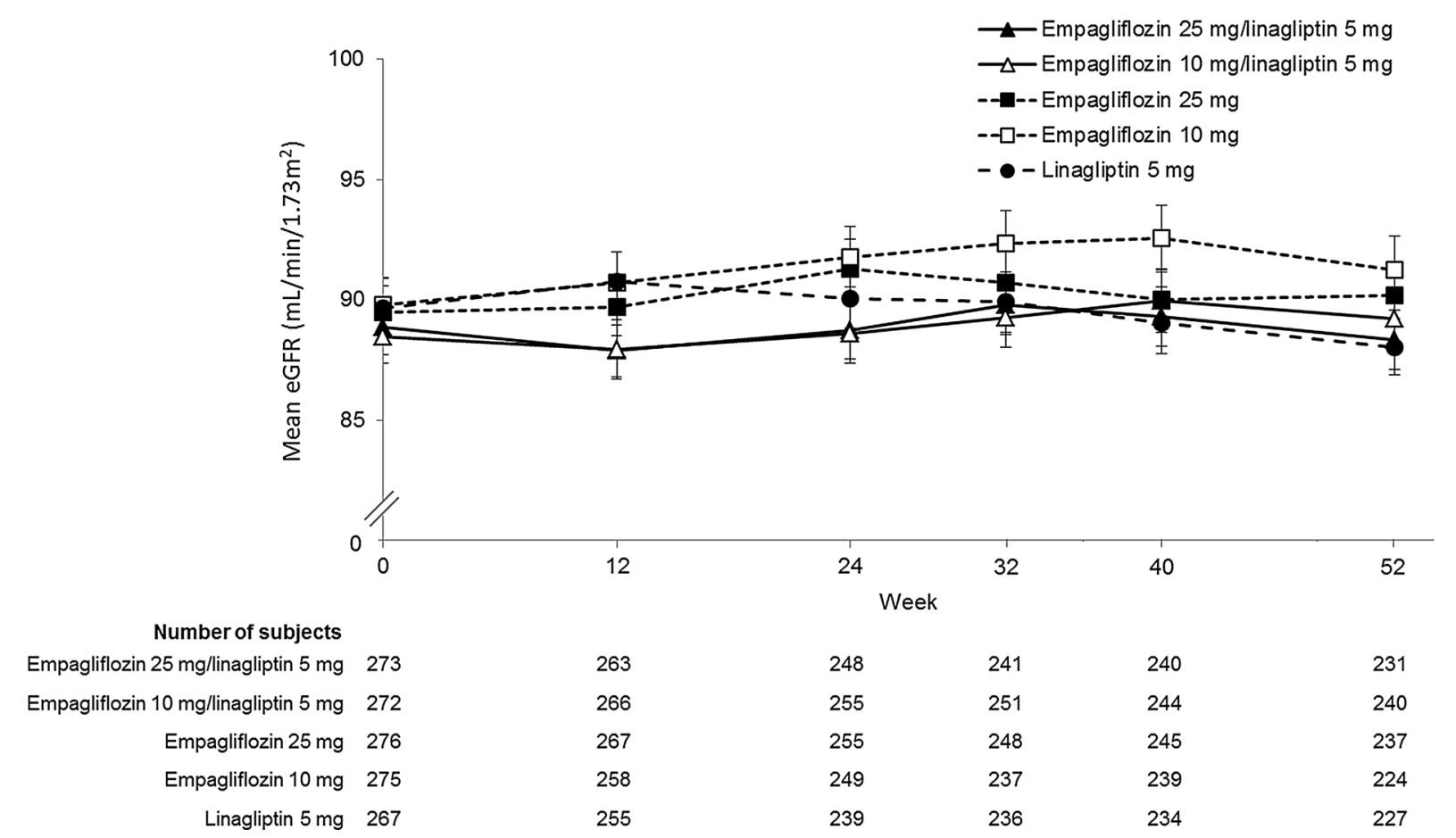

Fig. 1 Estimated glomerular filtration rate (eGFR; according to Modification of Diet in Renal Disease formula) over 52 weeks. Descriptive statistics in patients treated with $\geq 1$ dose of study drug. Data are mean \pm SE

Different types of cancer were reported in each group.

\section{Lipid Laboratory Parameters}

There were small increases from baseline in total cholesterol in the empagliflozin/linagliptin and the empagliflozin groups, and a small decrease in the linagliptin $5 \mathrm{mg}$ group (Table 4). There were small increases from baseline in HDL-cholesterol in all treatment groups. No consistent pattern was observed in changes from baseline in LDL-cholesterol; there were small decreases with empagliflozin $10 \mathrm{mg} /$ linagliptin $5 \mathrm{mg}$ and linagliptin $5 \mathrm{mg}$, and small increases in the other groups (Table 4). There was a decrease in triglycerides in the empagliflozin $25 \mathrm{mg}$ and linagliptin $5 \mathrm{mg}$ groups (Table 4).

\section{Other Laboratory Parameters}

Mean changes from baseline in hematocrit were +4.3 to $+4.9 \%$ in the empagliflozin/ linagliptin and empagliflozin groups and $+1.3 \%$ in the linagliptin group (Table 4 ). Mean changes from baseline in uric acid were -0.9 to $-1.1 \mathrm{mg} / \mathrm{dL}$ in the empagliflozin/linagliptin and empagliflozin groups and $+0.1 \mathrm{mg} / \mathrm{dL}$ in the linagliptin group (Table 4). There were no clinically meaningful changes in electrolytes (Table 4).

\section{DISCUSSION}

This analysis of pooled safety data from two 52-week Phase III trials was undertaken to further characterize the safety and tolerability of once daily empagliflozin/linagliptin compared with its individual components in patients with T2DM. Empagliflozin/linagliptin as monotherapy or add-on to metformin for 52 weeks were well tolerated, with safety profiles similar to the individual components. Most AEs were mild or moderate in intensity, and the proportion of patients with AEs leading to discontinuation was similar across treatment groups. Slightly higher percentages of patients had severe or 


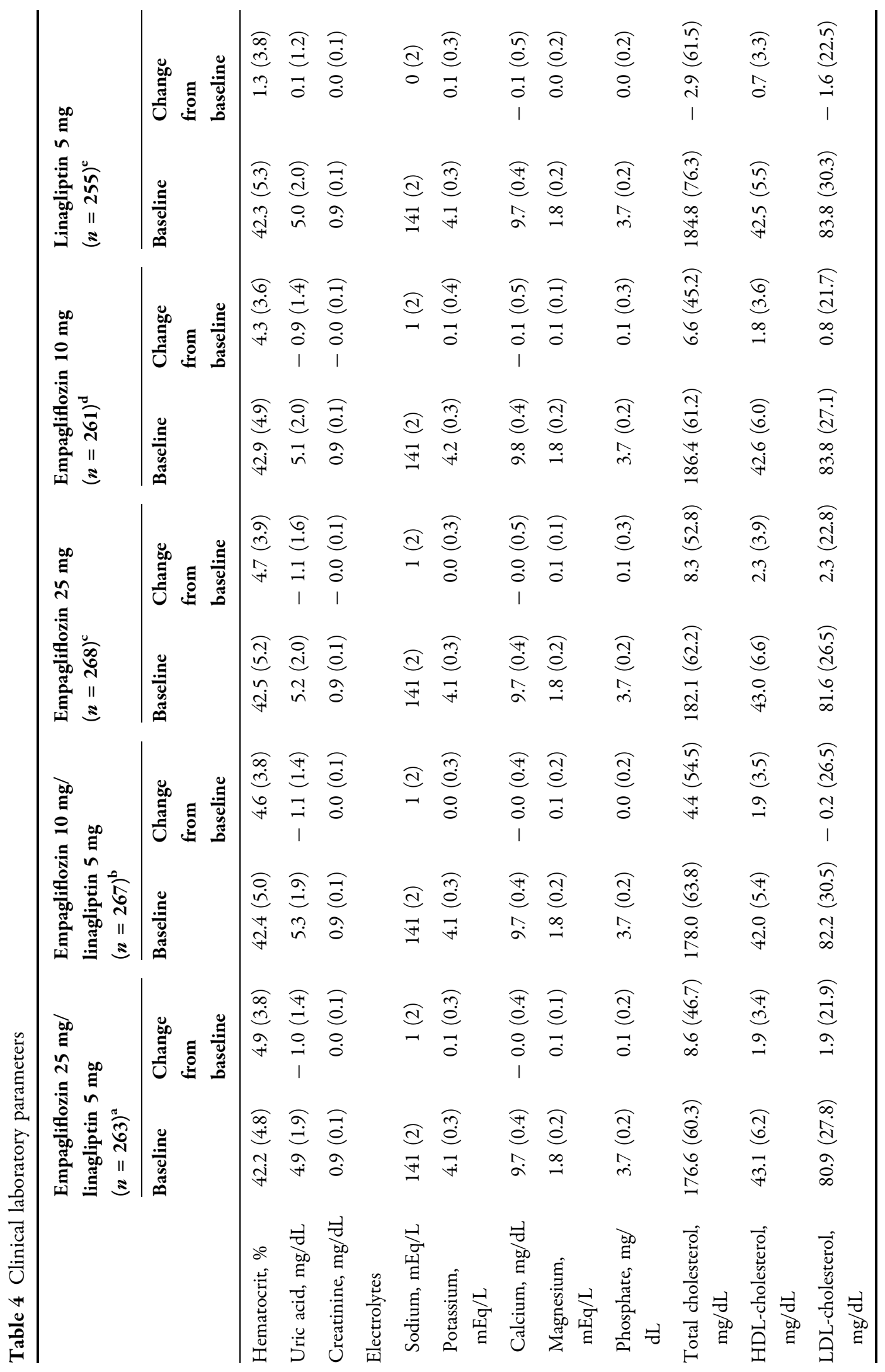




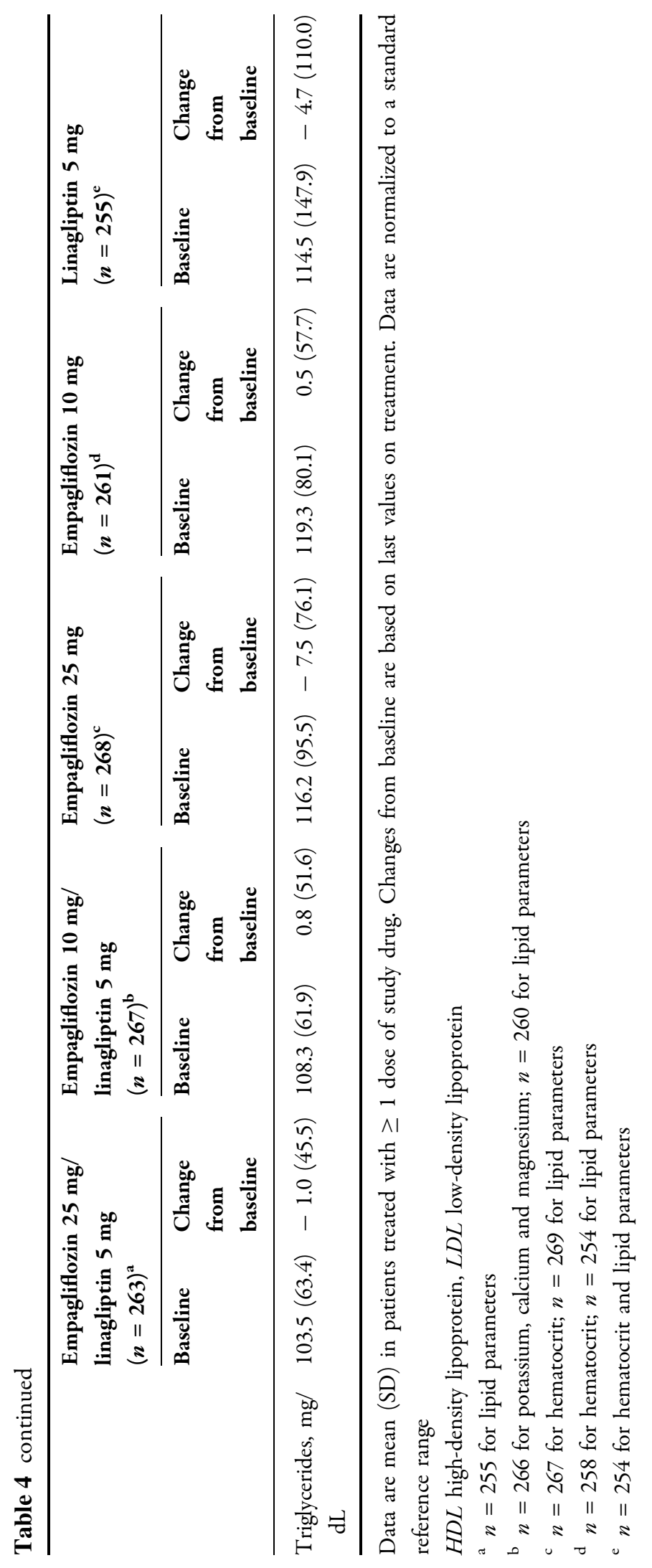


serious AEs with empagliflozin/linagliptin or empagliflozin compared with linagliptin.

Hypoglycemia is the major limiting factor in the glycemic management of T2DM [1]. The risk of hypoglycemia associated with each drug should be considered when choosing secondand third-line therapy [1]. Empagliflozin and linagliptin are associated with a low risk of hypoglycemia when given as monotherapy $[14,15]$ or as add-on to metformin [16-21]. Therefore, combination therapy with empagliflozin and linagliptin would not be expected to be associated with an increased risk of hypoglycemia. Further, the mechanism of action of empagliflozin is insulin-independent, and although linagliptin causes stimulation of insulin secretion and inhibition of glucagon secretion, these effects are glucose-dependent $[9,11]$. In this pooled analysis of $>1300$ patients receiving empagliflozin/linagliptin or individual components as monotherapy or addon to metformin, the proportion of patients with confirmed hypoglycemic AEs was low and similar across treatment groups, and no hypoglycemic AEs requiring assistance were reported.

In this pooled analysis, the proportion of patients with events consistent with UTI was similar in all groups. The proportion of patients with events consistent with genital infection was higher in patients on empagliflozin/linagliptin or empagliflozin than linagliptin, but no such events required or prolonged hospitalization. Most events consistent with UTI or genital infection were mild in intensity. Events consistent with UTI were reported in a greater proportion of females than males. Events consistent with genital infection were reported in a greater proportion of females than males except in the empagliflozin $25 \mathrm{mg} /$ linagliptin $5 \mathrm{mg}$ group. This observation in the empagliflozin $25 \mathrm{mg} /$ linagliptin $5 \mathrm{mg}$ group may be due to the low number of events. These findings are consistent with an analysis of pooled safety data from Phase I-III trials of empagliflozin in patients with T2DM in which the incidence of events consistent with UTI was not increased with empagliflozin but events consistent with genital infection occurred more frequently in participants treated with empagliflozin than placebo [22]. The risk of UTI or genital infections is not increased with linagliptin [15]. An increased risk of events consistent with UTI or genital infection is acknowledged in the product labels for empagliflozin [23] and empagliflozin/linagliptin [24].

Treatment with empagliflozin leads to osmotic diuresis $[25,26]$, which may lead to intravascular volume contraction and adverse reactions related to volume depletion or dehydration. The potential for volume depletion in vulnerable patients, such as the elderly, patients with renal impairment, patients with low systolic blood pressure, and patients receiving diuretics, is acknowledged in the prescribing information for empagliflozin [23] and empagliflozin/linagliptin [24]. In this pooled analysis, the risk of volume depletion (including dehydration) was low and similar between groups.

There have been post-marketing reports of serious hypersensitivity reactions and acute pancreatitis, including fatal pancreatitis, in patients treated with linagliptin [27]; this is acknowledged in the product labels for linagliptin [27] and empagliflozin/linagliptin [24]. In this pooled analysis, the risk of hypersensitivity reactions and pancreatitis was low across treatment groups.

In this pooled analysis, small changes in eGFR were observed in all treatment groups. Decreased renal function AEs were reported in only two patients. Changes from baseline in total cholesterol, LDL-cholesterol, HDL-cholesterol and triglycerides with empagliflozin/linagliptin were small and in line with those observed with empagliflozin in a large pooled analysis of safety data [22]. There were no clinically relevant changes in electrolytes in the present pooled analysis.

The strengths of this analysis are the large number of patients assessed and the 52-week duration of treatment. Limitations include the lack of a placebo arm in either of the studies.

\section{CONCLUSION}

In this pooled analysis of $>1300$ patients with T2DM, empagliflozin/linagliptin as monotherapy or add-on to metformin for 52 weeks was 
well tolerated, with safety profiles similar to individual components, including a low risk of hypoglycemia.

\section{ACKNOWLEDGEMENTS}

We thank the participants of the studies.

Funding. The studies that provided data for this analysis were funded by the Boehringer Ingelheim \& Eli Lilly and Company Diabetes Alliance. The article processing charges and Open Access fee were funded by Boehringer Ingelheim. The authors were fully responsible for all content and editorial decisions, were involved at all stages of manuscript development, and have approved the final version.

Medical Writing and Editorial Assistance. Medical writing assistance, supported financially by Boehringer Ingelheim, was provided by Melanie Stephens of FleishmanHillard Fishburn, London, UK, during the preparation of this manuscript. The authors also thank Isabella Zwiener of Boehringer Ingelheim for statistical review of this manuscript.

Authorship. All named authors meet the International Committee of Medical Journal Editors (ICMJE) criteria for authorship for this article, take responsibility for the integrity of the work as a whole, and have given their approval for this version to be published.

Prior Presentation. Some of the results of this pooled analysis were presented at the 75th Scientific Sessions of the American Diabetes Association, Boston, MA, 5-9 June 2015.

Disclosures. Ralph A. DeFronzo has served on scientific advisory boards for AstraZeneca, Boehringer Ingelheim, Elcelyx, Intarcia, Janssen, and Novo Nordisk; participated in speakers' bureaus for AstraZeneca and Novo Nordisk; and received grants/research support from AstraZeneca, Boehringer Ingelheim, Janssen, and Takeda. Sven Kohler is an employee of Boehringer Ingelheim. Christopher Lee was an employee of Boehringer Ingelheim at the time that these analyses were conducted.

Compliance with Ethics Guidelines. All procedures followed were in accordance with the ethical standards of the responsible committee on human experimentation (institutional and national) and with the Declaration of Helsinki in accordance with the International Conference on Harmonization Harmonized Tripartite Guideline for Good Clinical Practice. An independent ethics committee or institutional review board approved the clinical protocol at each participating center. All participants gave signed and dated informed consent prior to inclusion.

Data Availability. The datasets generated during and/or analyzed during the current study are available from the corresponding author on reasonable request.

Open Access. This article is distributed under the terms of the Creative Commons Attribution-NonCommercial 4.0 International License (http://creativecommons.org/licenses/ by-nc/4.0/), which permits any noncommercial use, distribution, and reproduction in any medium, provided you give appropriate credit to the original author(s) and the source, provide a link to the Creative Commons license, and indicate if changes were made.

\section{REFERENCES}

1. American Diabetes Association. Standards of medical care in diabetes-2018. Diabetes Care. 2018;41(Suppl. 1):S1-159.

2. Turner RC, Cull CA, Frighi V, Holman RR. Glycemic control with diet, sulfonylurea, metformin, or insulin in patients with type 2 diabetes mellitus: progressive requirement for multiple therapies (UKPDS 49). UK Prospective Diabetes Study (UKPDS) Group. JAMA. 1999;281:2005-12.

3. Kahn SE, Haffner SM, Heise MA, et al. Glycemic durability of rosiglitazone, metformin, or glyburide monotherapy. N Engl J Med. 2006;355:2427-43. 
4. Fonseca VA. Defining and characterizing the progression of type 2 diabetes. Diabetes Care. 2009;32(Suppl 2):S151-6.

5. DeFronzo RA. Banting lecture. From the triumvirate to the ominous octet: a new paradigm for the treatment of type 2 diabetes mellitus. Diabetes. 2009;58:773-95.

6. Hutchins V, Zhang B, Fleurence RL, et al. A systematic review of adherence, treatment satisfaction and costs, in fixed-dose combination regimens in type 2 diabetes. Curr Med Res Opin. 2011;27:1157-68.

7. Woo V. Empagliflozin/linagliptin single-tablet combination: first-in-class treatment option. Int J Clin Pract. 2015;69:1427-37.

8. Abdul-Ghani MA, Norton L, DeFronzo RA. Renal sodium-glucose cotransporter inhibition in the management of type 2 diabetes mellitus. Am J Physiol Renal Physiol. 2015;309:F889-900.

9. Gallo LA, Wright EM, Vallon V. Probing SGLT2 as a therapeutic target for diabetes: basic physiology and consequences. Diab Vasc Dis Res. $2015 ; 12: 78-89$.

10. DeFronzo RA, Norton L, Abdul-Ghani M. Renal, metabolic and cardiovascular considerations of SGLT2 inhibition. Nat Rev Nephrol. 2017;13:11-26.

11. Gallwitz B. Emerging DPP-4 inhibitors: focus on linagliptin for type 2 diabetes. Diabetes Metab Syndr Obes. 2013;6:1-9.

12. DeFronzo R, Lewin A, Patel S, et al. Combination of empagliflozin and linagliptin as second-line therapy in subjects with type 2 diabetes inadequately controlled on metformin. Diabetes Care. 2015;38:384-93.

13. Lewin A, DeFronzo R, Patel S, et al. Initial combination of empagliflozin and linagliptin in subjects with type 2 diabetes. Diabetes Care. 2015;38:394-402.

14. Roden M, Weng J, Eilbracht J, et al. Empagliflozin monotherapy with sitagliptin as an active comparator in patients with type 2 diabetes: a randomised, double-blind, placebo-controlled, phase 3 trial. Lancet Diabetes Endocrinol. 2013;1:20819.

15. Gomis R, Owens DR, Taskinen MR, et al. Long-term safety and efficacy of linagliptin as monotherapy or in combination with other oral glucose-lowering agents in 2121 subjects with type 2 diabetes: up to 2 years exposure in 24 -week phase III trials followed by a 78-week open-label extension. Int J Clin Pract. 2012;66:731-40.
16. Häring H-U, Merker L, Seewaldt-Becker E, et al. Empagliflozin as add-on to metformin in patients with type 2 diabetes: a 24 -week, randomized, double-blind, placebo-controlled trial. Diabetes Care. 2014;37:1650-9.

17. Merker L, Haering HU, Christiansen AV, et al. Empagliflozin as add-on to metformin in people with type 2 diabetes. Diabet Med. 2015;32:1555-67.

18. Taskinen MR, Rosenstock J, Tamminen I, et al. Safety and efficacy of linagliptin as add-on therapy to metformin in patients with type 2 diabetes: a randomized, double-blind, placebo-controlled study. Diabetes Obes Metab. 2011;13:65-74.

19. Schernthaner G, Barnett AH, Emser A, et al. Safety and tolerability of linagliptin: a pooled analysis of data from randomized controlled trials in 3572 patients with type 2 diabetes mellitus. Diabetes Obes Metab. 2012;14:470-8.

20. Ferrannini E, Berk A, Hantel S, et al. Long-term safety and efficacy of empagliflozin, sitagliptin, and metformin: an active-controlled, parallel-group, randomized, 78-week open-label extension study in patients with type 2 diabetes. Diabetes Care. 2013;36:4015-21.

21. Lehrke M, Marx N, Patel S, et al. Safety and tolerability of linagliptin in patients with type 2 diabetes: a comprehensive pooled analysis of 22 placebocontrolled studies. Clin Ther. 2014;36:1130-45.

22. Kohler S, Zeller C, Iliev H, Kaspers S. Safety and tolerability of empagliflozin in patients with type 2 diabetes: pooled analysis of Phase I-III clinical trials. Adv Ther. 2017;34:1707-26.

23. Boehringer Ingelheim Pharmaceuticals, Inc. Jardiance (empagliflozin) US Prescribing Information. 2017. https://www.accessdata.fda.gov/ drugsatfda_docs/label/2016/204629s008lbl.pdf.

24. Boehringer Ingelheim Pharmaceuticals, Inc. Glyxambi (empagliflozin and linagliptin) US Prescribing Information. 2017. https://www.accessdata.fda. gov/drugsatfda_docs/label/2015/206073s000lbl.pdf.

25. Heise $\mathrm{T}$, Jordan J, Wanner C, et al. Pharmacodynamic effects of single and multiple doses of empagliflozin in patients with type 2 diabetes. Clin Ther. 2016;38:2265-76.

26. Heise T, Jordan J, Wanner C, et al. Acute pharmacodynamic effects of empagliflozin with and without diuretic agents in patients with type 2 diabetes mellitus. Clin Ther. 2016;38:2248-64.

27. Boehringer Ingelheim Pharmaceuticals, Inc. Tradjenta (linagliptin) US Prescribing Information. 2017. https://www.accessdata.fda.gov/drugsatfda docs/label/2012/201280s005lbl.pdf. 